\title{
Responsabilidade Civil e Sustentabilidade: normatividade em prol do Meio Ambiente
}

\section{Civil Liability and Sustainability: normativity for Environmental improve}

\author{
Ana Cláudia Côrrea Zuin Mattos do Amaral \\ Universidade Estadual de Londrina, Londrina - PR, Brasil
}

\author{
Pedro Henrique Arcain Riccetto \\ Universidade de São Paulo, São Paulo - SP, Brasil
}

\begin{abstract}
Resumo: Este artigo analisa o caráter indissociável da responsabilidade civil e da sustentabilidade a partir dos novos paradigmas de ressarcimento, tecendo críticas ao sistema clássico de compensação, insuficiente para a promoção da justiça ambiental. Ancorado no método hipotético-dedutivo, assevera-se o caráter normativo da responsabilidade civil, que passa a apresentar, implicitamente, função regulatória de condutas, sob a rubrica de dano moral genérico. Demonstra-se, ao fim, que o atual paradigma de responsabilização, provido de função exclusivamente ressarcitória, não apresenta grau satisfatório de proteção ao Meio Ambiente.
\end{abstract}

Palavras-chave: Responsabilidade Civil. Sustentabilidade. Dano Extrapatrimonial. Regulação de Condutas.
Abstract: It analyzes the inseparable character of civil responsibility and sustainability from the new reimbursement paradigms in Brazilian law, criticizing the classical system of compensation, appointed as insufficient to the effective promotion of environmental justice. Sustained by the hypothetical-deductive method, it affir$\mathrm{ms}$ the normative nature of the liability, that starts to present normative function, albeit in a veiled way, always under the rubric of generic moral damage. It shows, in order, that the current liability paradigm, provided exclusively by compensatory function, does not present a satisfactory degree of protection to the environment.

Keywords: Civil Liability. Sustainability. Extrapatrimonial Damage. Normativity. 


\section{Introdução: sob os holofotes, a Responsabilidade Civil e a Sus- tentabilidade}

Os infortúnios do tradicionalismo acrítico conduziram dois jovens à tragédia, em singular narrativa de William Shakespeare datada do final do século XVI ${ }^{1}$. Subtraindo-se a essência da obra e repaginando-a aos desafios socialmente enfrentados hodiernamente, o ideal de sustentabilidade deve ser fundido às diretrizes da responsabilidade civil que, por rigorismos desmesurados, deixa de alcançar a abrangência necessária à efetiva proteção ambiental.

Sustentabilidade deve ser observada por lentes amplas, transcendendo a idoneidade nas relações privadas². Não é por menos que se faz menção à sua forma aberta, carecedora de resultados exatos e fixos (CANOTILHO, 210, p. 7-8) - ou seja, sustentabilidade não está adstrita ao dano ambiental, como outrora se pensou ${ }^{3}$, embora com ela esteja intimamente relacionado. Liga-se intimamente à manutenção de relações sociais equilibradas. E a ausência de tutela jurisdicional que impute responsabilização quando verificada lesão a interesse juridicamente relevante, ou mesmo antecipe a intervenção estatal a fim de evitar o dano, ocasiona assimetria na posição de lesante e de lesado.

Distanciando-se de uma visão panorâmica e atendo-se às especificidades que aqui se pretende observar, a sustentabilidade imprime formas também ao regramento ambiental; tem nele, inclusive, suas raízes teóri-

\footnotetext{
${ }^{1}$ Romeu e Julieta, romance escrito por William Shakespeare entre 1591 e 1595, narra a história de dois adolescentes apaixonados que, em razão de disputas entre suas famílias (Capuletos e Montecchios), reforçada pelas dificuldades trazidas pelo tradicionalismo próprio daquele momento histórico, optam, naquele episódio, por retirar suas próprias vidas como forma de uma demonstração mais profunda de amor.

2 Ignacy Sachs, na obra Caminhos para o desenvolvimento sustentável (2000), discute de forma aprofundada a extensão da sustentabilidade e suas interações com o desenvolvimento sustentável.

${ }^{3}$ Para uma reflexão mais aprofundada acerca do debate, consultar a obra de Ana Cláudia Côrrea Zuin Mattos do Amaral e Everon William Pona, Ampliando Horizontes: expansão da categoria dos danos ressarcíveis como garantia da responsabilidade jurídico-social nas relações privadas (2012).
} 
cas. Abarcada pelo texto constitucional, a sustentabilidade com viés ambiental não foge à regra: não se alcançará o meio ambiente equilibrado enquanto insuficientes os instrumentos próprios de defesa e preservação, dentre os quais se enquadra o sistema de responsabilidade civil.

Apoiado no método hipotético-dedutivo, o estudo demonstra a insuficiência da função ressarcitória ao atingimento dos fins constitucionais de proteção ao bem jurídico ambiental, por meio da análise dos novos paradigmas da responsabilização civil, competindo à doutrina refletir sobre a viabilidade da existência de um efetivo caráter regulatório de condutas, verificado pelo binômio prevenção-punição.

Assim, traçar-se-á, nas duas primeiras seções, a alteração dos paradigmas da responsabilidade civil clássica a partir de uma abordagem histórica e da desconstrução de noções clássicas não mais amparadas pela tônica constitucional pós-88, com a consequente revisitação da teoria geral do Direito Civil a partir de um encadeamento de eventos transformadores, inclusive a partir de estudo comparado.

As três seções subsequentes dedicam-se ao exame das funções da responsabilidade civil sob a ótica contemporânea e com viés ambiental, buscando-se afirmar, em prol da proteção ao Meio Ambiente, um sistema ressarcitório abrangente de maior grau de normatividade de condutas.

\section{Sai de Cena a Responsabilidade Civil Clássica}

O julgador não consegue conceder à responsabilidade civil aplicação que obedeça a critérios objetivos e balizados, ainda que possua anseios positivos. Diversas são as distorções teóricas da temática, responsáveis por mascarar conceitos por muitos considerados, inaplicáveis, além do que deixa $\mathrm{o}$ instituto de se atualizar de acordo com suas reais finalidades ${ }^{4}$.

\footnotetext{
${ }^{4}$ Quer-se dizer que, no recorte metodológico proposto, os tribunais vêm valendo-se da condenação ao ressarcimento pelo dano ambiental, a título de dano moral, a fim de extravasar o caráter meramente ressarcitório de que a responsabilidade civil atual é dotada.
} 
A situação torna-se insustentável quando o próprio ordenamento jurídico não é mais capaz de atribuir papeis, ou quando apenas cria personagens disformes, vagos, apagados. $\mathrm{O}$ ator, então, não sabe $\mathrm{o}$ que esperar. $\mathrm{O}$ espectador, muito menos. $\mathrm{O}$ suspense, tão prezado na ficção, aqui é sinônimo de insegurança jurídica e, se um ramo de direto tornou-se o centro das preocupações quanto à total imprevisibilidade de suas soluções é, sem sombra de dúvida, a responsabilidade civil. (LEVY, 2012, p. 2)

Não é uma hipérbole. A título de apoucados exemplos, pode-se dizer que o Superior Tribunal Justiça aplica indistintamente o "fortuito interno", exceção criada pela doutrina ao caso fortuito, sem o rigor científico primordial para subsumir o conceito à situação fática ${ }^{5}$; enquanto Pablo Malheiros da Cunha Frota (2014) denuncia o descaso da Corte ao fazer uso das teorias do nexo causal, e, após estudo empírico, observa a postura dos julgadores ao se valerem de subjetividade exacerbada ao determinar seu enquadramento no caso concreto - aproximando-se, em ambas as situações, de um verdadeiro jogo de azar.

Aliando-se à indefinição do caminho a ser seguido pelo julgador, subvertem-se os requisitos clássicos da responsabilidade civil, que se tornam, então, pragmaticamente desconsiderados, conforme a conveniência do caso posto. Portanto, passam a funcionar como mera formalidade vinculada ao resultado, já previamente estabelecido na consciência do magistrado (SCHREIBER, 2013, p. 11), evidenciando a falibilidade do instituto nos moldes atualmente aceitos.

O sistema reparatório brasileiro vem, em crescente escala, se mostrando insuficiente aos fins almejados, tornando o problema perceptível sob os diversos aspectos, notadamente quando comparado com institutos alienígenas responsáveis por promover um modelo mais eficiente de responsabilização civil, v. g., os torts norte-americanos e a tipificação dos danos adotada pelo sistema italiano e francês. Na experiência brasileira,

\footnotetext{
${ }^{5} \mathrm{O}$ quadro sinótico que integra a explicação referente ao conteúdo do REsp 1.269.691/ PB no "Informativo Esquematizado" do Informativo 534 do STJ, disponível no sítio < https://drive.google.com/file/d/0B4mQkJ-pSXwqUE9nOV9JREpDVlk/edit>, é bem elucidativo nesse sentido.
} 
usualmente se verifica a carência de efetividade diante dos não raros casos de reincidência contumaz do agente na prática do ilícito, que, embora condenado a promover o ressarcimento da lesão causada, não adota postura condizente com a licitude e confronta a ideia de sustentabilidade.

Sem adentrar em conceitos básicos, apresenta-se a culpa lato sensu como requisito da responsabilidade civil subjetiva: é dizer que, a fim de assegurar o ressarcimento, imprescindível a comprovação de dolo ou culpa do agente responsável pelo evento danoso. Ocorre que muitas vezes a prova da culpa onera desarrazoadamente o lesado, que, diante da ausência de prova, nesse sentido, permanece sem o ressarcimento devido.

Com o estopim que deflagrou as revoluções do fim do século XVIII, aliado aos ideais iluministas que emergiam, a ideia de culpa passou a dar espaço à noção de risco, que descartou o dever de comprovar a culpabilidade em hipóteses determinadas. Acrescenta-se a isso a evolução dos riscos tecnológicos, decorrente da evolução técnico-científica, e a postura dos tribunais, que propiciou a expansão da responsabilidade civil por meio da jurisprudência (HIRONAKA, 2006, p. 212). Da ideia de risco, adveio a responsabilidade objetiva, mais comumente aplicada nas relações consumeristas, igualmente merecedora de ressalvas, por compreender-se também como insuficiente à tutela merecida pelo lesado, eis que apresenta suporte fático limitado, num primeiro momento, às hipóteses em que existente previsão legal.

Frisa-se que não se pretende afirmar aqui o desaparecimento da culpa na responsabilidade civil - o que soaria inadequado, na medida em que imporia o dever de indenizar em situações em que a comprovação da culpa é muito razoável -, mas apenas busca-se demonstrar a mitigação sofrida por tal elemento nas últimas décadas de legislação e tradição jurisprudencial.

Diante da insuficiência in abstrato de indenizações limitadas à manutenção do status quo ante - isto é, limitadas à função ressarcitória - é que se propõem mecanismos a fim de assegurar ao lesado e à sociedade a fixação de quantum indenizatório mais condizente às situações de dano, adaptadas às nossas experiências constitucional, civil e ambiental. 
Colocando-se no centro das preocupações do sistema de responsabilidade não somente o homem, mas também o Meio Ambiente como bem jurídico constitucionalmente assegurado, não se justifica manter o formato até então aceito. Decidia-se, num primeiro momento, exclusivamente com foco na postura do lesante, mediante aferição de culpa, quando, posteriormente, passa-se a consideração da "vitimologia" como fator principal (LEVY, 2012, p. 25), o que torna secundária a aferição da culpa na conduta do causador do dano e populariza as teorias do risco.

Não mais sendo bastante para as propostas sustentáveis, passa-se a equiparar a conduta do agente àquela da vítima para fins de aferição da responsabilidade, deixando-as em patamar de igualdade: de um lado ressarce-se integralmente o dano, enquanto, de outro, a partir da superação do paradigma clássico, regulam-se condutas, por meio da prevenção e punição. É a nova configuração, que ora se propõe demonstrar aplicáveis ao Direito Ambiental - que, embora diante de bem jurídico difuso, vê-se compatível com as novas funções da responsabilidade civil. O reascender do debate sobre os alicerces da responsabilidade civil possibilita a sustentação, de forma mais substancial, de um modelo que permita maior e adequada atenção a bens jurídicos diversos do patrimônio - dentre os quais se inclui o Meio Ambiente - e, ainda que não esteja o sistema atual adstrito à proteção de interesses de cunho econômico (especialmente após a Constituição de 1988), permite a proteção a bens jurídicos existenciais em grau superior de efetividade, face ao caráter regulatório de condutas, que envolve a punição e a prevenção ${ }^{7}$.

\footnotetext{
"O termo "vitimologia" é adotado por Daniel de Andrade Levy em sua obra - e aqui transplantado - para se referir a um segundo momento histórico das indenizações, em que o dever de ressarcimento passa a levar em consideração mais a figura do lesado do que a culpa lato sensu do ofensor; justifica-se, assim, o despontamento das chamadas "teorias do risco" mundo afora.

${ }^{7}$ Não se pretende aqui ingressar na discussão acerca da indispensabilidade ou não de previsão legal específica para implementação das novas funções da responsabilidade civil. Busca-se apenas realizar um estudo comparativo de dois modelos teóricos.
} 


\section{A Ampliação do Dano Indenizável e a Responsabilização à Luz da Proteção Integral - uma Teoria Geral Revisitada}

Elevação do indivíduo ao centro do ordenamento, movimento marcado pela expansão da tutela da dignidade humana em meados do Século $\mathrm{XX}$, remonta também ao aqui abordado ideal de sustentabilidade, que se faz presente nas relações ambientais e foi incorporado na atual Constituição Federal ${ }^{8}$.

Guiado pelo eixo ético da alteridade (CUNHA FROTA, 2014, p. 22) e a ética do futuro (JONAS, 2006, p. 72-73), objetivando-se a justiça social (CUNHA FROTA, 2014, p. 22), a relevância jurídica que passa a ser dada a carência/insuficiência do "outro" à responsabilidade própria impactou diretamente na teoria geral de responsabilidade, que, gradativamente, passou a se distanciar de seu caráter individualista e essencialmente privado para se aproximar de noções de cooperação. Passa-se a observar uma reestruturação alicerçada na solidariedade, acarretando a pulverização do risco na busca da manutenção da estabilidade das relações sociais ${ }^{9}$.

Não há dúvidas da gradual ampliação da percepção de dano inserido na proposta. Segundo Levy (2012, p. 15), “[...] a lesão não é mais concreta, não é mais pontual, não é mais imediata e o tempo de vida do ser humano não coincide mais com a temporalidade do dano. Para o autor, "[...]o indivíduo se torna participante de uma aventura coletiva [...]", o que permite ampliar a concepção do dano à esfera ambiental, dada sua natureza difusa, outrora não detectável (LEVY, 2012, p. 15).

\footnotetext{
${ }^{8}$ Apesar de aparentemente contraditório, a proteção do princípio da dignidade da pessoa humana e o fortalecimento da teoria dos direitos fundamentais tornou possível a ampliação do ideal de sustentabilidade e uma proteção mais efetiva ao Meio Ambiente.

${ }^{9}$ Concretizando esses ideais, em boa representatividade do cenário apresentado, Giselda Hironaka chega a introduzir inclusive proposições que vão além e fundam o modelo de responsabilidade denominado por ela de pressuposta, inovando na doutrina brasileira ao defender de forma inequívoca os novos paradigmas da reparação, que, para evitar maiores divagações, apenas reporta-se brevemente.
} 
O movimento de ampliação pode ser percebido acentuadamente a partir de construção teórica da Suprema Corte Italiana, a qual reinventou, na histórica Sentenza n. 500/99, os alicerces da responsabilidade civil. A revolução é nítida na leitura do aresto:

E' noto que la giurisprudenza di questa S. C. ha compiuto una progressiva erosione dell' assolutezza del principio che vuole risarcible, ai sensi dell'art. $2043 \mathrm{CC}$, soltanto la lesione del diritto soggettivo, procedendo ad un constante ampliamento dell'area dela risarcibilità del danno aquiliano, quantomeno nei rapporti tra privati ${ }^{10}$.

Alterando-se o panorama, a lesão passa a ter como objeto não somente o direito subjetivo, mas também consagrado como a lesão a qualquer interesse caracterizado como legítimo e merecedor da tutela jurisdicional. E essa tendência leva à repercussão positiva na jurisprudência de nossos tribunais superiores.

Confluíram, diante do alargamento conceitual, sistemas dicotomicamente opostos: o aberto e o fechado. Neste, adotado na Itália e modificado substancialmente pelo teor da referida sentenza, pressupunha-se a tipificação do interesse ressarcível. No aberto, por sua vez, o legislador define cláusulas gerais para a responsabilização civil, responsáveis por conferir ao magistrado a discricionariedade para selecionar quais interesses devem ser objeto de tutela jurisdicional. É o sistema adotado no Brasil, que se vale de concepção aberta de ato ilícito nos artigos 186 e 927 do Código Civil.

A noção do que é efetivamente o interesse juridicamente legítimo, relevante e tutelado escapa à doutrina civil clássica. Os efeitos da mudança paradigmática somente expuseram a necessidade de se rever não só o conceito do dano em si, mas também do próprio instituto da responsabilidade civil. Na tentativa desenfreada de se abran-

\footnotetext{
10 Tradução livre: É sabido que a jurisprudência desta Corte de Cassação erodiu gradualmente o caráter absoluto do princípio de que ressarcível, nos termos do artigo 2.043 do Código Civil, apenas a lesão a direito subjetivo, progredindo a uma constante expansão da abrangência da ressarcibilidade do dano aquiliano, pelo menos nas relações entre particulares.
} 
ger cada vez mais situações fáticas ensejadoras de ressarcimento - por ótica até mesmo humanística - o julgador brasileiro classifica por vezes com atecnicidade quais são os danos ressarcíveis e a extensão dos demais pressupostos à indenização. (RICCETTO; REZENDE, 2013, p. 1)

Quanto ao dano, corriqueiro na prática judiciária, inclusive em recentes decisões do Superior Tribunal de Justiça, depara-se com a (im) procedência de determinada demanda ressarcitória fundada no sofrimento psicológico suportado pelo autor ou, ao revés, no mero dissabor cotidiano $^{11}$. Para a análise jurisprudencial, foram estabelecidos parâmetros de pesquisa para coleta de dados em recorte temporal específico (20102015), utilizando-se, no mecanismo de pesquisa do sítio eletrônico do STJ, as palavras-chave "sofrimento psicológico" e "mero dissabor". Obteve-se, respectivamente, 38 e 107 resultados em ações cíveis. Equivoca-se, porém, o Tribunal ao se amparar em tais condicionantes, pois determina a existência ou não do dano extrapatrimonial segundo os efeitos da lesão, e não ao interesse lesado, condicionando-a a um critério notoriamente subjetivo. Afinal, uma lesão de mesma intensidade é passível de ocasionar efeitos díspares a depender de particularidades do ofendido, e não pode a ressarcibilidade depender da sensibilidade de cada indivíduo, sob pena de gerar instabilidade ao sistema indenizatório.

Ao adotar critério diverso, com a desvinculação do dever de indenizar com base na repercussão dos efeitos da lesão, evita-se a compensação do dano a um interesse jurídico que, no caso concreto, e segundo o novo paradigma, embora causador de consequências no lesado como "sofrimento" e "mero dissabor", não se mostraria digno de tutela. Por outro

\footnotetext{
${ }^{11}$ Nesse sentido: "Como regra, o descumprimento de contrato, ao não pagar a seguradora o valor do seguro contratado, não enseja reparação a título de dano moral, salvo em situações excepcionais, que transcendam no indivíduo, a esfera psicológica e emocional do mero aborrecimento ou dissabor, próprio das relações humanas, circunstância essa que não se faz presente nos autos" (AgRg-AREsp 200.514, DJE 13/06/2013); "Mero descumprimento contratual não gera dano moral. Entretanto, se há recusa infundada de cobertura pelo plano de saúde -, é possível a condenação para indenização psicológica. (AgRg no Ag: 846077, DJE: 05/06/2007); e ainda EDcl-REsp 1.232.661, DJE 04/02/2013; REsp 1.329.189, DJE 21/11/2012; REsp 955.031, DJE 09/04/2012.
} 
lado, permite àquele que sofreu dano extrapatrimonial de mesma extensão, mas que, por razões pessoais, não se "abalou psicologicamente" ou "sofreu" em mesmo grau, de se ver ressarcido de acordo com a extensão da lesão ao interesse legítimo. Logo, "a definição de dano como lesão a um interesse tutelado [...] estimula a investigação sobre o objeto da lesão - o interesse da vítima efetivamente violado pelo ofensor -, a fim de se aferir o seu merecimento de tutela ou não, possibilitando a seleção dos danos ressarcíveis" (SCHREIBER, 2013, p. 109).

É compreensível a dificuldade do julgador em definir o interesse legítimo, à medida que a seleção não prescinde de análise que recai sobre o ordenamento jurídico como um todo. Cabe a ele sopesar quais lesões representaram violação a interesse legítimo, hábil a torná-lo digno de tutela na situação em concreto.

Daniel de Andrade Levy (2012, p. 29) elucida os efeitos decorrentes da ampliação conceitual, acompanhando uma tendência da responsabilidade civil de função tripartite, que extrapola a mera reparação:

A ampliação do leque de danos ressarcíveis, diretamente resultante da multiplicação dos direitos da personalidade, permitiu que a responsabilidade civil se imiscuísse nos mais variados meandros da sociedade, trazendo um instrumento poderoso para fazer da reparação moral muito mais do que uma mera restituição. Cada dano se torna a pedra fundamental de um edifício bem maior, que obraria para a punição do ofensor e a prevenção do ilícito. Como diriam os irmãos Mazeaud, no início do século XX, 'hoje os princípios da responsabilidade civil se tornaram a sanção geral de todas as regras do direito'. Não se hesita em recorrer à reparação tanto para temperar a aplicação de uma regra muito estrita quanto para aumentar as sanções que se estimam insuficientes: a reparação do dano se tornou a Régua de Lesbos da responsabilidade civil.

Em contraposição à contínua expansão do dano ressarcível, o rigorismo formal impede a responsabilidade civil de atingir a plenitude, além de impedir a efetivação de seu caráter regulatório de condutas. Daí se tem que a normatividade imposta pelas regras de responsabilização deve abranger, a despeito da função ressarcitória, concentrada no lesado, fun- 
ções precípuas de punição e prevenção, que direcionam suas lentes ao agente ofensor.

\section{E as Máscaras Caem: o caráter punitivo da Responsabilidade Civil}

Volta à cena a punição ${ }^{12}$, maquiada sob a forma de dano moral "genérico". O instituto reaproxima-se gradualmente da figura do ofensor, o que demonstra, por si só, que a "vitimologia" não é suficiente à estabilização das relações sociais e que, também, o grau de culpa passa a ter novamente papel de relevância dentro da responsabilidade civil, em alocação diversa. $\mathrm{O}$ foco na vítima como fundamento à indenização acarretou a perda de importância na observação da conduta do ofensor, mesmo para se definir, em inúmeras situações, o dever de indenizar - o que não mais seria possível com o retorno das indenizações punitivas.

Mais evidente ainda a insuficiência da análise do papel do lesado no âmbito ambiental, em que a lesão é perpetrada contra bem jurídico difuso e que, obrigatoriamente, não há sua participação, como, por exemplo, em situação de concausalidade. A responsabilidade civil passa a centrar sua atenção então somente na conduta do ofensor para fins de fundamento ressarcitório, superando o paradigma alhures enunciado.

A evolução doutrinária e jurisprudencial permitiu o amadurecimento da lógica da indenização, que não é - e nem pode ser - de via única, mas de retorno ao enfoque relacionado ao agir do ofensor, mediante aferição de seu comportamento na quantificação do dano extrapatrimonial.

O regramento atinente à indenização punitiva no Direito norte-americano varia significativamente em cada estado. Contudo, apenas admite-se sua aplicação caso o ofensor cometa ato ilícito imbuído de um determinado estado de espírito, característico, portanto, do elemento culpa, indissociável de grande parte dos atos ilícitos. Há uma variação dos graus

\footnotetext{
${ }^{12}$ Como será demonstrado no decorrer dessa seção, houve momento histórico em que pena e indenização se dissociavam, o que veio ocorrer, no âmbito normativo, somente com a Lex Aquilia de Damno.
} 
do aludido estado de espírito, que, do mais reprovável para o mais brando, seriam (i) malícia (malice); (ii) intenção (intent); (iii) temeridade (recklesness); e (iv) negligência (negligence) (JOHNSTON; MARKESINIS, 2008, p. 939).

No sistema jurídico norte-americano, as indenizações punitivas destinam-se, pois, a sancionar e desestimular condutas ilícitas cometidas de forma maliciosa, intencional ou temerária, vedando-se aplicabilidade aos casos de mera negligência. Assim, são dotados de relevância ao se quantificar os punitive damages a verificação da gravidade ou grau de reprovabilidade da conduta que deu ensejo ao ato ilícito, bem como a extensão e natureza dos prejuízos suportados pela vítima e, também, a capacidade econômica do ofensor, que, "[...] a despeito de irrelevante para a fixação dos compensatory damages, é importante para a quantificação dos punitive damages, uma vez que a quantia suficiente para apenar sensivelmente um homem comum pode ser indiferente para uma grande corporação." (WILCOX, 2009, p. 257)

Tornando a ideia clara, passaram os tribunais estadunidenses a levar em consideração para apuração do quantum debeatur (i) a reprovabilidade da conduta lesiva, observando-se as funções punitivas e dissuasórias; (ii) a condição econômica do agente; (iii) a conduta das partes no processo; e, por fim, (iv) a aplicação da indenização punitiva somente caso não seja suficiente a verba compensatória para a punição do réu, tornando-a complementação indenizatória em casos de insuficiência ${ }^{13}$. Ou seja, diversos aspectos da conduta lesiva são apurados no caso concreto, para o arbitramento do valor, o que demostra a superação do caráter meramente reparatório, tendo essa ampliação sido afirmada ainda pela Suprema Corte.

Breve análise histórica mostra-se essencial à aceitação das funções punitivas e preventivas da responsabilidade civil - amplamente aplicáveis aos danos extrapatrimoniais decorrentes de lesões ao meio ambiente, que passaremos, no momento adequado, à detida reflexão. Compilando o desenvolvimento histórico da matéria, tem-se que

${ }^{13}$ Kuddus v. Chief of Leicestershire Constabulary (2002) AC 122 e Cassel \& Co. v. Broome and Another (1972) AC 1.027. 
Pena e reparação do dano são ambos oriundos da mesma fonte. Se Aguiar Dias afirma que "foi o sentimento legalista que transformou a vingança privada nos institutos da pena e da reparação do dano, acrescentaríamos que, posteriormente, foi uma preocupação política que afastou os dois conceitos. A conjuntura específica do Império Romano nos faria herdar essa separação que, em última instância, ficaria consagrada no inabalável dogma da summa divisio, em que a pena corresponderá ao Direito Público, e a reparação ao Direito Privado". No entanto, a função punitiva que a reparação do dano moral tem assumido hoje começa a desafiar esse dogma. A insistência em tentar impedir um movimento que parece natural é que tem distorcido institutos e categorias da responsabilidade civil atual. Não surpreendem, portanto, os dizeres de Fischer, para quem o dano moral incorporou um papel intermediário entre a indenização e a pena. A pena jamais foi esquecida, mas apenas constrita no interior do dano extrapatrimonial, em uma dissimulação que tinha tudo para agradar tanto aos que alegavam "barbárie" da pena quanto aos que afirmavam a imoralidade do "dinheiro da dor". (LEVY, 2012, p. 42-43)

A função punitiva da responsabilidade civil remanesce controversa no sistema brasileiro, encontrando-se adeptos de sua aplicabilidade em caráter excepcional ${ }^{14}$. Há quem sustente também o cabimento da punição por meio da responsabilidade civil no caso dos chamados "danos sociais" ". Todavia aduz-se que, no Brasil, tal função vem sendo canalizada pela ampliação interpretativa do dano moral, isto é, maquia-se a função punitiva em interpretações alargadas do dano moral, cujos aplicadores do direito passaram a abranger também o desestímulo à prática de novas condutas transgressoras. Da análise de diversos julgados atinentes à indenização extrapatrimonial, possível verificar que nossos tribunais vêm aplicando, em suma, os critérios de (i) gravidade da culpa; (ii) repercus-

\footnotetext{
${ }^{14}$ Maria Celina Bodin de Moraes sustenta a aplicabilidade da indenização punitiva no Direito brasileiro, ressalvada a necessidade de tipificação das hipóteses objetivas ensejadoras dessa modalidade ressarcitória, em respeito ao princípio da legalidade ( $\mathrm{Na}$ medida da pessoa humana: estudos de Direito Civil-Constitucional, 2010, p. 378).

15 Cf. lição de Carlos Roberto Gonçalves, na obra Direito Civil Brasileiro Responsabilidade Civil (2016, p. 563).
} 
são social do dano; e (iii) reprovabilidade da conduta e condições socioeconômicas dos envolvidos (SCHREIBER, 2013, p. 50). Nada mais são do que derivativos que colocam em prática a ideia de retorno do ofensor ao centro da preocupação, assumindo a mesma posição em que situada a vitima ao analisarmos o caráter reparatório. É o que a jurisprudência vem chamando de dano moral "exemplar", "pedagógico", "punitivo" ou "com caráter de desestímulo" (LEVY, 2012, p. 75).

Fica evidente a deformidade da indenização a título de (maquiada de) dano moral, que se pretende exclusivamente reparatória diante da nossa legislação, mas que, em verdade, adota critérios que são, em sua essência, punitivos. As construções teóricas de Andrade Levy e Schreiber são substanciais ao demonstrar a teratologia:

Em suma, convive-se hoje, no Brasil, com uma "espécie bizarra de indenização", que, embora não seja reconhecida formalmente como punitiva, reflete critérios que obram nessa direção, gerando absurda insegurança jurídica, tanto para a vítima quanto para o ofensor. Nos dizeres de Schreiber, "ao responsável não é dado conhecer em que medida está sendo apenado, em que medida se está simplesmente compensando o dano". Completamos o raciocínio do autor afirmando que à vítima também não é dado conhecer o verdadeiro fato gerador de sua reparação e a natureza de sua indenização, o que teria suma importância, inclusive em sua motivação para ingressar em juízo. A esquizofrenia do dano moral talvez seja, hoje, o mais grave problema da responsabilidade civil brasileira. Mostra que a função punitiva da disciplina continua constrangida sob figuras totalmente imprevisíveis, tanto em quantidade quanto em qualidade. Enquanto não se refletir acerca de uma categoria autônoma de indenização punitiva, ou ao menos de uma verba autônoma no âmbito dos danos morais, deverá o jurisdicionado contentar-se com o esforço de fundamentação das decisões que nem sempre se coadunam com a nossa carregada justiça.

E, ao adentrarmos às novas categorias de dano moral, se torna inequívoca a faceta punitiva que integra as indenizações, mas especialmente visível no direito ambiental, dentro do dano moral coletivo - que é o que se busca demonstrar na seção seguinte, exclusivamente dedicado a 
demonstrar como o dano moral coletivo advindo de lesão ao Meio Ambiente pode deixar claro que a punição já integra nosso Direito Civil e Ambiental, mesmo que de forma não revelada.

\section{A Função Punitiva do Dano Moral Coletivo no Direito Ambiental}

Já denunciada em mais de uma oportunidade a insuficiência do Direito Civil clássico à tutela integral daqueles direitos que ultrapassam a esfera individual, dentre os quais se atém, agora, aos ambientais ${ }^{16}$. A dificuldade advém, dentre os outros problemas, de sua natureza difusa, contrapondo-se àquela ideia inicial de vítima como pessoa física identificável.

O interesse difuso se difere do individual, na medida em que apresenta características de maior generalidade e abstração, que ultrapassam a soma daqueles interesses individuais de que são possuidores os indivíduos isoladamente (CRETELLA NETO, 2012, p. 872).

Há, atualmente, com o reconhecimento desses interesses, novas modalidades de ressarcimento e, também, nova perspectiva de se considerar o dano ambiental, que conquista maior espaço. Nesse contexto situam-se o (i) dano ambiental interino (ou intercorrente), (ii) dano residual e (iii) o dano moral coletivo. Pelo primeiro, fala-se em dano pela privação do desfrute do Meio Ambiente pela comunidade no período - transitório em que impossibilitada a restauração da área, isto é, o "hiato passadiço de deterioração, total ou parcial, na fruição de bem de uso comum do povo" (STJ, REsp 119872/MG); por dano residual entende-se, por sua vez, a devastação ambiental que permanece, apesar das tentativas de restauração (STJ, REsp 119872/MG); dano moral coletivo é conceituado pela doutrina como "a injusta lesão da esfera moral de uma dada comunidade, ou seja, a violação antijurídica de um determinado círculo de valores coleti$\operatorname{vos}^{17 ”}$, ou mesmo a “[...] lesão injusta e intolerável a interesses ou direi-

${ }^{16}$ Pela possibilidade de configuração do dano moral coletivo: REsp 1.269.494/MG; REsp 1.367.923/RJ. Em sentido contrário: REsp 971.844/RS; REsp 598.281/MG.

17 É o conceito dado por Carlos Alberto Bittar Do dano moral coletivo no Direito Brasileiro, (2009) e também por Patrícia Faga Iglecias Lemos (2010, p. 165) 
tos titularizados pela coletividade" (MEDEIROS NETO, 2014, p. 137). O Superior Tribunal de Justiça ainda não estabilizou a jurisprudência acerca da viabilidade ou não do dano moral coletivo ${ }^{18}$.

São danos que atingem uma coletividade, e que a reparação a cada uma das vítimas lesadas é, ainda assim, insuficiente à estabilização social. A condenação à recuperação da área degradada também não exime o ofensor do dever de indenizar os danos extrapatrimoniais sofridos.

Dado seu caráter transgeracional, árdua a tarefa de mensurar o dano ambiental. Sendo perceptíveis seus efeitos muitas vezes apenas no decorrer de algum tempo, não se consegue medir a extensão do dano de plano, o que inviabiliza a própria aplicabilidade do conceito de reparação integral à situação. Não havendo meios de o magistrado se valer da chamada teoria da diferença, usualmente aplicável aos danos materiais em geral, acaba ele se vendo compelido à aplicação de critérios que dizem respeito ao dano sob o aspecto da conduta.

Embora em situações de danos intercorrentes ou residuais seja possível a constatação da restrição, pela comunidade, do bem ambiental, e sua extensão em dado momento - o que dificultaria, assim, falar em caráter punitivo nesses casos, embora não se possa antever o período de transitoriedade nos danos intercorrentes -, o viés normativo se torna indubitável ao analisarmos o dano moral coletivo, conforme Andrade Levy demonstra, utilizando-se de passagem de Ripert, responsável por esclarecer que "[...] a indenização não poderá, de forma alguma, compensar o dano sofrido pela coletividade ou por seus membros" (RIPERT apud LEVY, 2012, p. 88-89), de modo que não há como se negar a aplicação da feição punitiva, observada na prática forense mediante o arbitramento de indenizações baseada no grau de culpa do responsável pelo dano ambiental.

Evidente que sem saber a extensão do dano, ainda que extrapatrimonial, não se pode falar apenas em ressarcir - situação ainda mais clara quando a indenização acaba sendo arbitrada, em verdade, de acordo com

\footnotetext{
${ }^{18}$ É o conceito dado por Carlos Alberto Bittar $e$ também por Patrícia Faga Iglecias Lemos (2010, p. 165)
} 
a gravidade da conduta do agente ao lesar o Meio Ambiente, forma de arbitramento do quantum debeatur próprio da indenização que visa punição.

O regime do denominado dano extrapatrimonial ambiental acaba por clarificar sua natureza punitiva, que, embora não expressamente acolhida pela doutrina e jurisprudência, acaba sendo mais facilmente perceptível após as considerações feitas, necessárias à alteração do pensamento contemporâneo e construção de um sistema mais adequado à solução dos novos problemas.

\section{Responsabilidade Civil não é Remédio: melhor prevenir do que remediar}

É difícil a separação entre a ideia de sustentabilidade e o próprio desenvolvimento econômico, uma vez que a sociedade contemporânea vive um contexto peculiar, com preponderante economia de mercado e guiada, por isso, pela racionalidade do lucro. O dispêndio de valores envolvidos ao pagamento de indenizações ou mesmo a adoção de mecanismos de prevenção do dano ambiental passam a ser vistos, em regra, sob a rubrica de custos, a despeito do impacto socioambiental gerado.

Acrescenta-se a esse cenário a prática contumaz de ilícitos que acabam por gerar lucro ao agente ofensor, que deixa de alterar sua conduta pela ausência de um sistema sancionatório eficaz. Não é diferente no Direito Ambiental, muitas vezes relacionado às práticas de setores industriais e empresariais que possuem o Meio Ambiente como matéria-prima para suas atividades, e que optam pela prática de lesões em massa diante da vantagem econômica delas advinda.

Volvendo-se à resolução dos problemas, o caráter regulatório difuso da responsabilidade civil reclama aplicabilidade, com o acréscimo da perspectiva preventiva, que introduz aspecto socializante decorrente de toda a evolução do instituto. $\mathrm{O}$ impacto social decorrente de regulação mais intensa nessa seara permite a tutela mais efetiva do bem ambiental, 
cujo retorno ao status quo apresenta maiores dificuldades do que em lesões de outra natureza.

Deve-se pensar em um novo modelo, em que a "[...] a responsabilidade civil estabeleça tanto os danos previsíveis quanto os imprevisíveis, assim como os danos presentes e futuros" (CARVALHO, 2008, p. 125). É aqui que se inserem as noções de prevenção e precaução, próprias, num primeiro momento, do Direito Ambiental.

Na prevenção, Cretella Neto (2014, p. 225) afirma estarmos diante de um risco conhecido e que "pretende-se administrá-lo, adotando medidas apropriadas, que levam em consideração as características desse risco, já conhecido e mensurável com razoável grau de precisão". Já o princípio da precaução "[...] baseia-se na ideia de que potencial risco ou incerteza deva ser interpretado com vistas à adoção de determinada medida de salvaguarda [...]”, daí decorrendo que, segundo esse princípio, “[...] a mera cogitação da existência de algum risco potencial à saúde ou ao meio ambiente, ainda que não suficientemente comprovado de forma científica, justifica a adoção de medidas que evitem o dano temido" (CRETELLA NETO, 2014, p. 223).

Sedimentam-se os princípios da prevenção e precaução à responsabilidade civil pelo ideal de risco, ou seja, surge uma bifurcação importante que decorre da junção teórica de ambos: de um lado o risco grave passa a ser considerado como um dano em si, apto a ensejar o dever de reparação; e de outro, a prevenção como decorrência lógica do caráter punitivo da indenização, mediante regulamentação difusa de condutas.

O segundo aspecto acaba por ficar evidente a partir das digressões argumentativas despendidas no estudo. Por sua vez, o risco como dano em si se torna tutelável em razão de toda a mudança estrutural exposta: a extensão do conceito de dano, o próprio contexto histórico da evolução e caráter constitucional dos bens jurídicos envolvidos, além da solidariedade e alteridade hoje impregnada à responsabilidade civil. O STJ, inclusive, mostra a possibilidade de vermos o risco como um dano em $\mathrm{si}^{19}$.

${ }^{19}$ REsp $1.424 .304 / \mathrm{SP}$ 
A nova possibilidade não deve ser vista, porém, como irrestrita. A doutrina impõe limitações à sua aplicabilidade, consistentes essencialmente do "contexto da incerteza científica", próprio da precaução, e a "eventualidade de dano graves e irreversíveis" (LE TOURNEAU; CADIET, 1996). Deixa-se, ainda, claro que a ideia não é nova, mas, em verdade, uma "[...] redescoberta, sob um novo nome, da virtude moral e jurídica de prudência, no sentido aristotélico." (LE TOURNEAU apud LEVY, 2012, p. 22).

Com efeito, transportou-se as atenções da conduta lesiva ao risco da coisa, culminando na responsabilidade objetiva que hoje conhecemos. Ainda insuficiente, necessita-se de uma nova alteração no foco, agora fundado na proteção integral do indivíduo e do meio ambiente, não mais limitado ao mero ressarcimento, mas com impacto social e econômico efetivo por meio de regulação mais estrita de condutas que se relacionam com o Meio Ambiente.

A história revelou que mudar é preciso. Conforme os anseios sociais se alteram, cabe ao Direito percebê-los e a eles amoldar-se, garantindo-se assim a necessária coesão, evitando-se tornar uma ciência desvinculada da realidade. As proposições apresentadas passam novamente a ser fruto de debate mais amplo, levado a toda a comunidade jurídica, ingressando-se em proposta de reformulação da própria teoria geral da responsabilidade civil, sem que se limite, neste primeiro momento, à legislação vigente, porque passível de alteração pelos instrumentos próprios.

\section{Conclusão}

Mostra-se insuficiente a responsabilidade civil nos moldes clássicos, mesmo que sob o aspecto objetivo, visto que o mero ressarcimento do dano não compreende a proteção integral almejada, especialmente enquanto o bem jurídico lesado é o meio ambiente. A noção de sustentabilidade aliada à dinâmica da responsabilidade civil permite falar-se em um caráter normativo proveniente da indenização, que pode ser observado pela aplicação, nos danos extrapatrimoniais, das funções preventivas e punitivas. 
Assim, retorna à centralidade do instituto a conduta do ofensor, há tempo olvidada, para auxiliar o arbitramento da indenização. Alia-se à vitimologia, própria da teoria do risco, para cumprir um caráter de regulação difusa de condutas. A responsabilidade civil por danos ambientais obedece, portanto, à análise não somente do dano em si, diante das dificuldades de mensurá-lo, mas também da ofensividade do agente - critério comumente adotado no arbitramento do quantum debeatur. Parcela da doutrina e jurisprudência oculta uma função punitiva da responsabilidade civil, utilizando-a embutida em interpretação alargada do conceito de dano moral, abarcando especificidades das questões ambientais, tais como a dificuldade de mensuração do próprio dano. Torna-se nada mais do que concentrar diversos institutos dotados de características próprias em uma única via de solução, dotada, diante da atecnicidade, de exacerbado subjetivismo.

Deve-se também obediência, consagrando o caráter regulatório readquirido pela responsabilidade civil, à prevenção e precaução, que agora mesclam-se à teoria geral, impondo-se um padrão de conduta. Em função preventiva bifurcada, o risco passa a ser considerado, em determinadas hipóteses, um dano em si, e a função punitiva acaba por dissuadir a repetição do ilícito. Daí concluir-se que a responsabilidade civil por danos ambientais não somente sofreu, em decorrência da constitucionalização do Direito, alterações que permitem a proteção de interesses jurídicos extrapatrimoniais, de cunho não econômico portanto, dentre os quais os ambientais, mas também que impõe-se a ela uma normatividade condizente com a sustentabilidade, em relação simbiótica.

\section{Referências}

AMARAL, Ana Cláudia Côrrea Zuin Mattos do; PONA, Everon William Pona, Ampliando Horizontes: expansão da categoria dos danos ressarcíveis como garantia da responsabilidade jurídico-social nas relações privadas. In: KEMPFER, Marlene; ESPOLADOR, Rita de Cássia Resquetti Tarifa. (Org.). Estudos em Direito Negocial e Sustentabilidade. Curitiba: CRV, 2012. p. 9-12. 
BITTAR, Carlos Alberto. Do dano Moral Coletivo no Direito Brasileiro. Florianópolis: BuscaLegis CCJ.UFSC.br. [2009].

CANOTILHO, José Joaquim Gomes. O princípio da sustentabilidade como princípio estruturante do direito constitucional. Revista de Estudos Politécnicos - Polytechnical Studies Review, [S.l.], v. VIII, n. 13, p. 7-18, 2010.

CARVALHO, Délton Winter de. Dano ambiental futuro: a responsabilização civil pelo risco ambiental. Rio de Janeiro: Forense Universitária, 2008.

CORTE DI CASSAZIONE. Sentenza della Corte di Cassazione 22 luglio 1999, n. 500. Itália [1999]. Disponível em: <http://www. sanzioniamministrative.it/collegamenti/RicercaGiuridica/sentenze/ CassazioneCivile/Cass_Civ_500_1999-Unite.pdf $>$. Acesso em: 9 mar. 2016.

CRETELLA NETO, José. Curso de direito internacional do meio ambiente. São Paulo: Saraiva, 2012.

CUNHA FROTA, Pablo Malheiros. Responsabilidade por danos: imputação e nexo de causalidade. 1. ed. Curitiba: Juruá, 2014.

\section{. Palestra Nexo causal na Responsabilidade Civil}

brasileira. 2014. Disponível em: <https://www.youtube.com/ watch? $v=q I h R 7 F 8 n L v s>$. Acesso em: 8 jan. 2016.

ESPOLADOR, Rita de Cássia Resquetti Tarifa. Estudos em direito negocial e sustentabilidade. Curitiba: CRV, 2012.

GONÇALVES, Carlos Roberto. Direito Civil Brasileiro:

Responsábilidade Civil. II. ed. Saraiva: São Paulo, 2016.

HIRONAKA, Giselda Maria F. Novaes. Responsabilidade pressuposta: evolução de fundamentos e de paradigmas da responsabilidade civil na contemporaneidade. In : DELGADO, Mário Luiz; ALVES, Jones Figueiredo (Org.) Novo Código Civil - Questões Controvertidas: Responsabilidade Civil. São Paulo: Médoto, 2006. (v. 5) 
JOHSON, A.; MARKESINIS, B. Markesinis and Deakin's Tort Law. New York: Oxford, 2008.

JONAS, Hans. O princípio da responsabilidade: ensaio de uma ética para a civilização tecnológica. Tradução de Marijane Lisboa e Luiz Barros Montez. Rio de Janeiro: Contraponto; Editora PUC-Rio, 2006. LE TOURNEAU, Phillipe; CADIET, Loic. Droit de la responsibilité. Paris: Dalloz, 1996.

LEMOS, Patrícia Faga Iglecias. Dano Ambiental: responsabilidade civil e proteção ao meio ambiente. 3. ed. São Paulo: Revista dos Tribunais, 2010.

LEVY, Daniel de Andrade. Responsabilidade Civil: de um direito dos danos a um direito das condutas lesivas. São Paulo: Atlas, 2012.

MEDEIROS NETO, Xisto Tiago de. Dano moral coletivo. 4. ed. São Paulo: LTR, 2014.

MORAES, Maria Celina Bodinde. Na medida da pessoa Rumana:

Estudos de Direito Civil. Rio de Janeiro: Renovar, 2010.

RICCETTO, Pedro Henrique Arcain; REZENDE, Lucas Teixeira de. Interesse Legítimo e o Superior Tribunal de Justiça. 2013. Disponível em: $<$ http://paquetejuridico.blogspot.com.br/2013/11/interesse-legitimoe-o-superior.html>. Acesso em: 20 jan. 2016.

SACHS, Ignacy. Caminhos para o desenvolvimento sustentável. Rio de Janeiro: Garamond, 2000.

SILVA, José Afonso da. Direito Ambiental Constitucional. 8. ed. São Paulo: Malheiros, 2010.

SCHREIBER, Anderson. Novos paradigmas da responsabilidade civil: da erosão dos filtros da reparação à diluição dos danos. 5. ed. São Paulo: Atlas, 2013.

WILCOX, Vanessa. Punitive Damages: Common Law and Civil Law Perspectives. Wien: Springer, 2009. 
Ana Cláudia Côrrea Zuin Mattos do Amaral é professora de graduação e pósgraduação em Direito na Universidade Estadual de Londrina, doutora em Direito das Relações Sociais pela Pontifícia Universidade Católica de São Paulo, mestre em Direito Negocial pela Universidade Estadual de Londrina e graduada em Direito pela mesma instituição.

E-mail: anaclaudiazuin@live.com.

Endereço profissional: Universidade Estadual de Londrina, Centro de Estudos Sociais Aplicados, Departamento de Direito Privado, Rodovia Celso Garcia Cid Km 380, Campus Universitário, Londrina, PR - 86051-990.

Pedro Henrique Arcain Riccetto é doutorando em Direito do Estado pela Universidade de São Paulo, mestre em Direito Negocial pela Universidade Estadual de Londrina, especialista em Direito Constitucional Contemporâneo pela Universidade Estadual do Norte do Paraná e graduado em Direito pela Universidade Estadual de Londrina.

E-mail: pedroriccetto@gmail.com.

Endereço profissional: Universidade de São Paulo, Faculdade de Direito, Largo São Francisco 95, São Paulo, SP - 01005-010 
